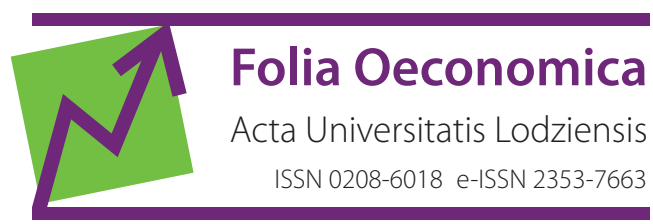

www.czasopisma.uni.lodz.pl/foe/

3(335) 2018

DOI: http://dx.doi.org/10.18778/0208-6018.335.01

\title{
Sebastian Twaróg
}

University of Economics in Katowice, Faculty of Management, Department of Social Logistics, sebastian.twarog@ue.katowice.pl

\section{Anna Ojrzyńska}

University of Economics in Katowice, Faculty of Informatics and Communications, Department of Demography and Economics Statistics, anna.ojrzynska@ue.katowice.pl

\section{Usability of Spatial Analysis for Improving the Functioning of the Blood Donation System in Poland}

\begin{abstract}
The paper aims at understanding how blood resources are formed at the entrance to the blood donation in the spatial and age section and formulating on the basis of this assessment recommendations that help improve the health safety of the State in the area of self-sufficiency of blood supplies. The success of the functioning of blood donation primarily depends on the resource management of blood and its components that seeks to equate supply and demand for blood and its components at any time. Such a situation is possible when a sufficient number of blood donors are available. The research employed a shift-share analysis that is used to study structural changes in economic and social phenomena that may occur in a geographical area within a specified period of time. To account for the fact that each province does not exist as a separate geographic area but depends on its spatial interactions with neighbouring areas, the study also used a spatial shift-share analysis. The results will be used to assess the dynamics of changes in the number of blood donors, resulting from the age structure of blood donors in a particular province (a structural effect) and from changes in the internal situation of the competitiveness of a given area (a geographic effect). Knowledge concerning the nature of these changes can be helpful in developing specific tools that would encourage donors (including the potential ones) to donate blood.
\end{abstract}

Keywords: blood donation, migration selectivity index, shift-share analysis, spatial shift-share analysis JEL: R15 


\section{Introduction}

The success of the functioning of blood donation primarily depends on the resource management of blood and its components that seeks to equate supply and demand for blood and its components at any time (Twaróg, 2013). The issue of managing blood resources in Poland encompasses: 1) the specificity of blood as an unlimited medicine, 2) the requirements of national ${ }^{1}$ and international legislation ${ }^{2}$. The proper management of blood resources is one of the prerequisites for seeking improvement in terms of temporary blood shortages in some areas of the system as well as periods when the amount of accumulated blood in the system exceeds the demand for blood. Both shortages and surpluses accumulated in the blood system distribution are highly detrimental to the health security of the State, as well as to the process of developing public awareness (Twaróg, 2012).

Full understanding of principles governing the management of blood resources is extremely difficult because of:

1. The situation in the system is dynamic and uneven across Poland (Trzpiot et al., 2013) .

2. The civil-public blood donation system operates in parallel with the armed forces blood donation system (Szołtysek, Twaróg, 2009; 2010). Despite the lack of cooperation between these systems, they derive from the same resources (donors), using the same health procedures, and similar organisational procedures.

3. Large volumes of data gained from events and processes that constitute daily activities of the blood donation system lower the efficiency of possible information that may be taken and used for the management of this system. One of the problems is also the fact that policymakers are primarily doctors without managerial skills at the required level (Twaróg, 2015).

Considering the above and according to studies carried out ${ }^{4}$ in Poland - the number of donors is an essential element 'powering' the system of civil (public)

${ }^{1}$ As a self-sufficient country.

${ }^{2}$ The principle of voluntary unpaid donation of blood (Directive 2002/98/EC of the European Parliament and of the Council of 27 January 2003).

${ }^{3}$ The dynamics of changes in the structure of blood donors (first-time and repeat) from 2006 to 2009 as a source of knowledge about the problems of "powering" the civilian blood donation in Poland in terms of blood and its components has been already presented in the paper: Wykorzystanie shift-share analysis w opisie zmian struktury honorowych dawców krwi w Polsce (Use of Shift-share Analysis of Changes in the Description of the Structure of Blood Donors in Poland).

${ }^{4}$ The regression analysis helped determine the precise impact of a significant determinant. Two models describing the relationship between the number of inhabitants per one donor and the number of inhabitants per unit of whole blood (Model I ) and blood, together with its components (Model II ), were received. Model I $: y=6.27+0.94 x$, Model II $: y=0.93+1.25 x$. In both models, it is right to say that the decline by a unit of the population per one donor will reduce a waiting list for a unit of blood by around half a person (Twaróg, 2012). 
blood donation in Poland. Therefore, the authors of this paper decided to reach for statistical methods to understand how blood resources are formed at the entrance to the blood donation in the spatial and age section and on the basis of this assessment to formulate recommendations aimed at improving the health safety of the State in the area of self-sufficiency of blood supplies.

Analysed data from the National Blood Centre (Narodowe Centrum Krwi - NCK) provided the material for this study. All collected data referred to the civil blood donation system in Poland. Data on the age structure of the population come from the Central Statistical Office.

\section{Research methods}

\subsection{Migration Selectivity Index}

In the broad sense, a manifestation of selectivity is the diversity of the impact of the specific characteristics of the population propensity to occurrence of a phenomenon. In the study, as a measure of the tendency, we will use Migration Selectivity Index (MSI) (Cieślak, 1992) adapted to compare the age structure of blood donors against the Polish population.

The definition of the index is written in the form:

$$
M S I_{V=i}=\frac{\frac{M_{V=i}}{M}-\frac{P_{V=i}}{P}}{\frac{P_{V=i}}{P}},
$$

where:

$V$ - the variable due to which the selectivity of the phenomenon (age) is studied,

$i$ - the category of the $V$ variable for which the ratio value is calculated, $M S I_{V=i}$ - the selectivity ratio with respect to the $V$ variable for the $i$ category, $M_{V=i}$ - the size of the studied subpopulation in the $i$ category and the $V$ variable,

$M$ - the total size of the studied subpopulation,

$P_{V=i}$ - the size of the studied population in the $i$ category and the $V$ variable, $P$ - the total size of the studied population.

This index may be in the range of $[-1 ;+\infty]$. Positive values indicate the presence of positive selectivity, all the higher the higher the value of the index. This means that a given phenomenon involves more entities of a given category than their proportion in the general population (Mioduszewska, 2008: 16). 
It is said that the selectivity phenomenon does not occur when the values of this index equal zero or are close to zero. MSI can also be used to determine which of the studied traits strongly select the subpopulation of a given area ${ }^{5}$.

\subsection{Shift-share analysis}

The shift-share analysis (SSA) (Creamer, 1942) examines the evolution of the TX variable quantified as a complex: the increase in the absolute or relative growth (the rate of change) of the $\mathrm{X}$ variable. The output is, therefore, the $t x_{r i}$ value of the TX variable, where $r$ is the index corresponding to the $r$-th region and the $i$ subscript is the index of the $i$-th group by the cross-sectional division (Suchecki, 2010: 162).

In the simplest case, the reference distribution is the most marginal distribution of the analysed variable $\mathrm{X}$ in the initial period. Three types of weights can then be applied in analyses (Suchecki, 2010: 163):

1) regional weights $w_{r \bullet(i)}=\frac{x_{r i}}{x_{r \bullet}}$, where $x_{r \bullet}=\sum_{i} x_{r i}(r=1,2, \ldots, R)$,

2) sectoral weights $w_{\bullet i(r)}=\frac{x_{r i}}{x_{\bullet i}}$, where $x_{\bullet i}=\sum_{r} x_{r i}(i=1,2, \ldots, S)$,

$$
\text { individual weights } w_{r i}=\frac{x_{r i}}{x_{\bullet \bullet}}, \text { where } x_{\bullet \bullet}=\sum_{r} \sum_{i} x_{r i} .
$$

In addition to the individual growth rate of the value of the $\mathrm{X}$ variable in the $i$-th sector and the $r$-th region, which is defined as:

$$
t x_{r i}=\frac{x_{r i}^{*}-x_{r i}}{x_{r i}},
$$

where: $x_{r i}^{*}$ is the observation of the analysed variable $X$ in the $r$-th region and the $i$-th group of cross-distribution in the final period; aggregate measures are used in the SSA (Suchecki, 2010: 164):

1. The average growth rate of the $\mathrm{X}$ variable in the $r$-the region:

$$
t x_{r \bullet}=\sum_{i} w_{r \bullet(i)} t x_{r i},
$$

2. The average growth rate of the $\mathrm{X}$ variable in the $i$-th sector:

${ }^{5}$ In the demographics, however, the Migration Selectivity Index is frequently used to examine an impact of certain (often unobserved) factors that make the structure of the migrant population of the area different from the structure of the population in a given area. 


$$
t x_{\bullet i}=\sum_{r} w_{\bullet i(r)} t x_{r i},
$$

3. The average growth rate of the $X$ variable in a country in a given period:

$$
t x_{\bullet \bullet}=\frac{\sum_{r} \sum_{i}\left(x_{r i}^{*}-x_{r i}\right)}{\sum \sum x_{r i}} .
$$

The application of shift-share analysis in the study of changes in the economic or social phenomena in different regions is based on the decomposition of the total change in the localised variable $\mathrm{X}$ into three components, reflecting.

4. The national (global) part of regional development $M_{r i}$.

5. The structural part of regional development $E_{r i}$.

6. The local part of regional development $U_{r i}$.

The classical shift-share equation in the growth rates (year-on-year growth) of the analysed variable adopts the following form (Suchecki, 2010: 164):

$$
t x_{r i}=t x_{\bullet \bullet}+\left(t x_{\bullet i}-t x_{\bullet \bullet}\right)+\left(t x_{r i}-t x_{\bullet i}\right) .
$$

Thus the individual components of (8) equation have the following interpretation:

1) $m=t x_{\bullet \bullet}$ the national or global rate of regional growth,

2) $e_{i}=t x_{\bullet i}-t x_{\bullet \bullet}$ the sectoral (structural) factor of regional growth,

3) $u_{r i}=t x_{r i}-t x_{\bullet i}$ the local (geographic, competitive, differentiating) growth factor in the $i$-th sector of the $r$-th region.

In contrast, pure regional growth, defined as the difference between the regional and national growth rate, can be decomposed into two components (structural and geographical):

$$
t x_{r i}-t x_{\bullet \bullet}=\left(t x_{\bullet i}-t x_{\bullet \bullet}\right)+\left(t x_{r i}-t x_{\bullet i}\right)
$$

In calculating the regional average for the three components of the equation, we come to the following formula called structural and geographic equality (Suchecki, 2010: 165):

$$
t x_{r \bullet}-t x_{\bullet \bullet}=\sum_{i} w_{r \bullet(i)}\left(t x_{\bullet i}-t x_{\bullet \bullet}\right)+\sum_{i} w_{r \bullet(i)}\left(t x_{r i}-t x_{\bullet i}\right)
$$

Nazara and Hewings (2004) incorporated the spatial structure within this basic formulation, taking into account spatial interaction in the decomposition analysis. As a result, they proposed the following formulation (Nazara, Hewings, 2004):

$$
t x_{r \bullet}-t x_{\bullet \bullet}=\sum_{i} w_{r \bullet(i)}\left(W t x_{\bullet i}-t x_{\bullet \bullet}\right)+\sum_{i} w_{r \bullet(i)}\left(t x_{r i}-W t x_{\bullet}\right),
$$


where $W$ defines, in this case, a matrix of geographical neighbourhood ${ }^{6}$ with values different from zero for the spatially adjacent regions.

\section{Empirical analysis}

\subsection{Determination of a nationwide pattern of age selectivity of blood donors}

In the first part of the paper, the analysis of the selectivity pattern of blood donors at the national level based on their age was carried out. The selectivity indices are constructed based on a comparison of the number of blood donors in different age groups in the age structure of the population, i.e. people aged 18-65. The results summarised in Table 1 support the conclusion that in the case of the age structure of blood donors, we have to deal with the phenomenon of selectivity, although with respect to certain age groups, the selectivity is much stronger than in the others. The MSI values for the group aged 18-24 give the clearest picture in this respect. This means that the share of this age group of blood donors was $281 \%$ higher than among the total number of persons aged 18-24. Those aged $45-65$ were less likely to donate blood, as evidenced by $M S I=-0.67$.

Table 1. The total MSI values of the age of blood donors

\begin{tabular}{|c|c|c|c|}
\hline \multirow{2}{*}{ MSI $_{v=i}$} & Age group 18-24 & Age group 25-44 & Age group 45-65 \\
\cline { 2 - 4 } & 2.81 & 0.28 & -0.67 \\
\hline
\end{tabular}

Source: own elaboration

\subsection{Determination of regional age selectivity patterns of blood donors}

The patterns of age selectivity of blood donors in the provinces are similar to the national values. The index values for the Lubuskie province are noteworthy. In this province, the most evident is the overrepresenativeness of the youngest group of blood donors $(M S I=3.93)$. Negative values of indices in the other age groups indicate that people in these age groups gave blood much less frequently than would result from the age structure of the population of the Lubuskie province.

${ }^{6}$ Let $W^{*}$ denote a neighbourhood matrix defined as $W_{i j}^{*}= \begin{cases}1 ; & \text { if regions } i \text { and } j \text { are neigbours } \\ 0 ; & \text { if not }\end{cases}$ the diagonal elements of this matrix are also zero. Matrix $W$ is the result of a row-standardisation of $W^{*}$ obtained dividing each of the elements of the $i$-th row of $W^{*}$ by the sum of the elements of the row, $\sum_{j} W_{i j}$ (Márquez, Ramajo, Hewings, 2009). 
Table 2. MSI age values of blood donors in the analysed provinces

\begin{tabular}{|l|c|c|c|}
\hline \multicolumn{5}{|c|}{ MSI $_{\boldsymbol{v}=\boldsymbol{i}}$} \\
\hline Province & Age group 18-24 & Age group 25-44 & Age group 45-65 \\
\hline Dolnośląskie & 2.96 & 0.20 & -0.65 \\
\hline Kujawsko-Pomorskie & 2.90 & 0.09 & -0.64 \\
\hline Lubelskie & 3.69 & 0.21 & -0.69 \\
\hline Lubuskie & 3.93 & -0.13 & -0.72 \\
\hline Łódzkie & 3.48 & 0.13 & -0.66 \\
\hline Małopolskie & 2.98 & 0.04 & -0.68 \\
\hline Mazowieckie & 2.87 & 0.20 & -0.63 \\
\hline Opolskie & 3.09 & 0.11 & -0.63 \\
\hline Podkarpackie & 3.07 & -0.03 & -0.69 \\
\hline Podlaskie & 2.85 & 0.15 & -0.70 \\
\hline Pomorskie & 3.07 & 0.09 & -0.66 \\
\hline Śląskie & 2.52 & 0.34 & -0.63 \\
\hline Świętokrzyskie & 3.07 & 0.09 & -0.63 \\
\hline Warmińsko-Mazurskie & 3.24 & -0.02 & -0.71 \\
\hline Wielkopolskie & 2.83 & 0.13 & -0.70 \\
\hline Zachodniopomorskie & 3.10 & 0.16 & -0.72 \\
\hline
\end{tabular}

\section{Changes in the number of blood donors in the period 2010-2014}

This part of the paper presents the changes occurring between 2010 and 2014, expressed by the calculated growth rates ${ }^{7}$ respectively for the number of blood donors in total, the number of donors aged 18-24, the number of donors aged 25-44, and the number of donors aged 45-65. Table 3 shows the calculated regional growth rates and the comparison of these rates to the national average growth rate of the number of blood donors. The largest increase in the total number of blood donors took place in the Podkarpackie province and amounted to 33.18\%. Also, the Warmińsko-Mazurskie, Lubuskie, Świętokrzyskie, Mazowieckie provinces are characterised by a high regional growth rate of blood donors in general. The smallest increase was recorded in the Opole province (8.59\%). Comparing the regional growth rates of individual provinces with the national average increase $\left(t x_{\bullet \bullet}=15.07 \%\right)$, the regions with the total increase in the number of blood donors higher than the

\footnotetext{
${ }^{7}$ The growth rate is calculated as a year-on-year growth.
} 
national average (Podkarpackie, Warmińsko-Mazurskie, Lubelskie, Świętokrzyskie, Mazowieckie, Podlaskie, Małopolskie) can be seen, as well as a group of provinces with an increase in the number of blood donors in general below the average of the country (provinces: Opolskie, Śląskie and Kujawsko-Pomorskie, Pomorskie, Łódzkie, Lubuskie, Dolnośląskie, Wielkopolska). While looking at the change in the number of blood donors in different age groups, the province with the most dynamic changes in the age group 18-24 years was the Śląskie province $(-39.52 \%)$, for which the deviation from the national average stood up at 16.47 percentage points. In contrast, the Lubuskie province in this period recorded an increase in the number of blood donors aged $25-44$ of $163.29 \%$ which is 59.07 percentage points higher than the average in the country (104.22\%). In turn, the Warmińsko-Mazurskie province can boast of the highest growth in terms of blood donors aged 45-65. There, the regional growth rate of blood donors in this age group was $37.47 \%$, thus it was higher by 30.94 percentage points than the national average $(6.53 \%)$. 


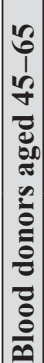

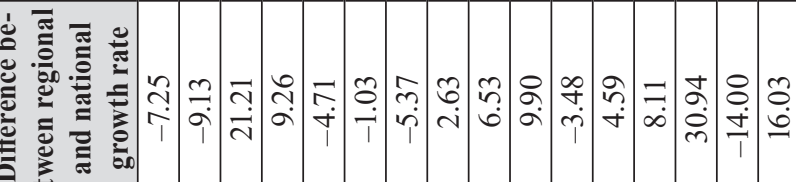

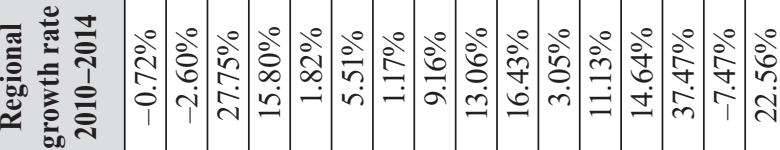

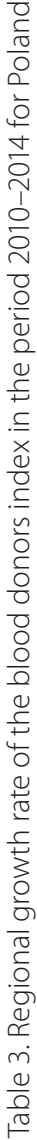

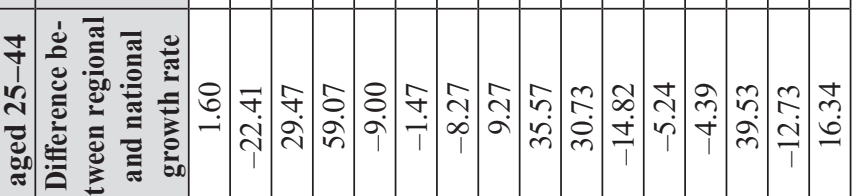

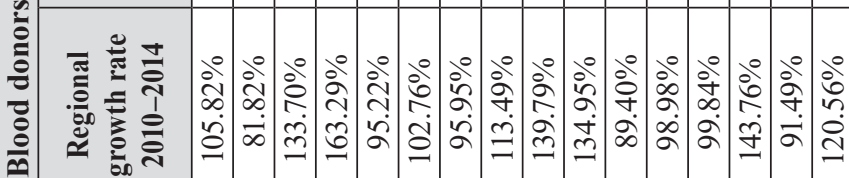

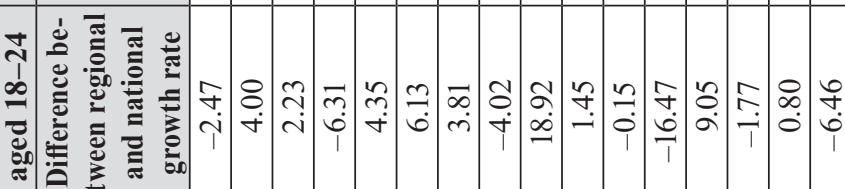

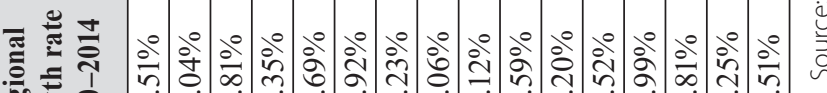

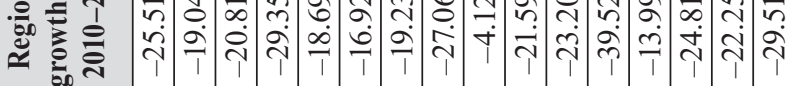

\begin{tabular}{|c|c|c|c|c|c|c|c|c|c|c|c|c|c|c|c|}
\hline 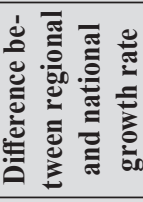 & $\stackrel{m}{\stackrel{n}{0}}$ & $\stackrel{m}{\stackrel{m}{+}}$ & $\tilde{n}$ & $\vec{\sim}$ & $\frac{I}{i}$ & م⿱⺈. & $\begin{array}{l}0 \\
m \\
m \\
m\end{array}$ & 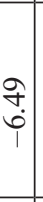 & $\begin{array}{l}\exists \\
\infty \\
\infty\end{array}$ & \begin{tabular}{l}
$\stackrel{2}{:}$ \\
\hdashline
\end{tabular} & & $\begin{array}{lll}0 & \infty \\
\dot{f} & \end{array}$ & $\begin{array}{lll}0 \\
:\end{array}$ & $\begin{array}{l}0 \\
\tilde{0} \\
0\end{array}$ & $\underset{ヘ}{\sim}$ \\
\hline 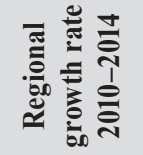 & $\begin{array}{l}\stackrel{\circ}{+} \\
\stackrel{?}{ \pm} \\
\stackrel{ \pm}{ \pm}\end{array}$ & 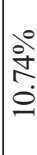 & $\begin{array}{l}\frac{0}{0} \\
\frac{0}{0} \\
0\end{array}$ & $\begin{array}{l}\stackrel{0}{0} \\
\infty \\
\stackrel{2}{0}\end{array}$ & $\begin{array}{l}\stackrel{0}{0} \\
\stackrel{0}{a} \\
\mathrm{I}\end{array}$ & $\begin{array}{l}0 \\
0 \\
0 \\
0 \\
0 \\
0\end{array}$ & $\mid \begin{array}{c}0 \\
\stackrel{0}{\sigma} \\
\infty \\
0\end{array}$ & $\begin{array}{l}\stackrel{0}{0}^{\circ} \\
\tilde{n}^{2}\end{array}$ & $\begin{array}{l}0 \\
\infty \\
\infty \\
\dot{m} \\
\text { ஸे }\end{array}$ & $\begin{array}{l}0 \\
0 \\
0 \\
0 \\
0 \\
0\end{array}$ & 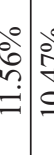 & $\begin{array}{ll}0 \\
+ \\
0 \\
0 \\
0\end{array}$ & $\hat{l}_{0}^{\circ}$ & $\begin{array}{l}\stackrel{0}{0} \\
\stackrel{2}{ \pm}\end{array}$ & $\begin{array}{l}\stackrel{0}{\circ} \\
\dot{D} \\
\text { తj }\end{array}$ \\
\hline & $\begin{array}{l}\frac{0}{\sqrt{n}} \\
\frac{\pi}{w} \\
\frac{0}{0} \\
\frac{0}{0}\end{array}$ & 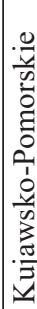 & $\begin{array}{l}\frac{0}{2} \\
\frac{2}{0} \\
\frac{0}{3} \\
3\end{array}$ & $\begin{array}{l}\frac{0}{\sqrt[n]{n}} \\
\frac{0}{3} \\
\frac{0}{3}\end{array}$ & 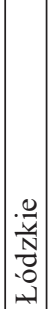 & 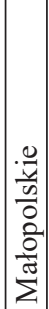 & 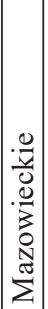 & $\begin{array}{l}\frac{0}{\frac{0}{n}} \\
0 \\
0 \\
0\end{array}$ & 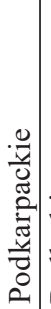 & 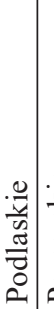 & 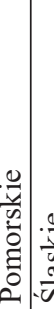 & $\frac{0}{\frac{0}{y}}$ & 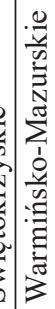 & 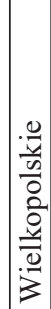 & 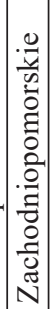 \\
\hline
\end{tabular}




\section{Structural and geographical analysis of blood donors between 2010 and 2014}

The analysis was carried out in relation to the reference area, which was the territory of Poland, and its results show the change in the number of blood donors in the provinces $(r=1,2, \ldots R$, where $R=16)$ compared with the level of development of the whole country. The regional weights in the form of shares of the analysed variable were used in the calculations.

The changes in the number of blood donors described in the previous section could result both from changes in the age structure of blood donors in particular provinces (a structural effect) and from the changes in the internal situation of the competitiveness of a given area (a geographic effect). The structural effect may be affected by: the population, migration, age structure of the population, economic burdens, as well as factors and causes of death, fertility, and health. The geographic effect may be affected by: public relations of the Regional Blood Donation and Blood Treatment Centre, the number of ambulances to collect blood and branch offices, changes in organisational structures of Regional Blood Donation and Blood Treatment Centres, increased competition, unemployment in a given region of Poland, investment, social benefits or the income level. The evaluation of the structural and geographic effects in the analysed provinces is presented in Table 4.

Table 4. Decomposition of growth rate in the number of blood donors between 2010 and 2014

\begin{tabular}{|l|c|c|}
\cline { 2 - 3 } \multicolumn{1}{c|}{} & Structural effect & Geographic effect \\
\hline Dolnośląskie & $1.23 \%$ & $-1.96 \%$ \\
\hline Kujawsko-Pomorskie & $0.64 \%$ & $-4.97 \%$ \\
\hline Lubelskie & $-5.76 \%$ & $10.29 \%$ \\
\hline Lubuskie & $-9.59 \%$ & $8.38 \%$ \\
\hline Łódzkie & $-1.96 \%$ & $-0.16 \%$ \\
\hline Małopolskie & $-2.86 \%$ & $3.45 \%$ \\
\hline Mazowieckie & $4.41 \%$ & $-1.05 \%$ \\
\hline Opolskie & $-6.19 \%$ & $-0.29 \%$ \\
\hline Podkarpackie & $-3.56 \%$ & $21.67 \%$ \\
\hline Podlaskie & $-7.82 \%$ & $8.58 \%$ \\
\hline Pomorskie & $1.16 \%$ & $-4.67 \%$ \\
\hline Śląskie & $5.61 \%$ & $-10.21 \%$ \\
\hline Świętokrzyskie & $-1.81 \%$ & $5.49 \%$ \\
\hline Warmińsko-Mazurskie & $-4.71 \%$ & $11.34 \%$ \\
\hline Wielkopolskie & $4.74 \%$ & $-5.08 \%$ \\
\hline Zachodniopomorskie & $-3.63 \%$ & $1.35 \%$ \\
\hline
\end{tabular}

Source: own elaboration 
An increase in the number of blood donors in the Podkarpackie province of $33.18 \%$, or 18.1 percentage points, over the average growth rate in the country was caused to a lesser extent by the structural changes in the age of blood donors $(-3.56 \%)$, and to a greater extent by the internal changes occurring in this region (geographic effect $=21.67 \%$ ). However, in the Lubuskie province, an increase in the number of blood donors below the average $(-1.21$ percentage points below the national average) was mainly caused by unfavourable changes in the age structure (structural effect $=-9.59 \%$ ).

\section{Conclusions}

The empirical research conducted by the authors allowed to illustrate changes in the structure and number of blood donors in Poland, as an element of 'powering' the civil system of blood donation in the country - The decline in the number of donors in the youngest age group in all the provinces is alarming, especially when this age group is most prone to blood donation. Considering the above, several recommendations aimed at improving the health security of the State in the area of self-sufficiency in blood supplies can be specified:

1. The age group 25-44, which recorded the highest increase in the number of blood donors in recent years, should be stimulated as the selectivity ratio in this group is only 0.28 .

2. The age group $45-65$, now by far the least prone to donate blood $(M S I=-0.67)$, should be stimulated. Despite the fact that the limitations within the group associated with a higher probability of failing health are known.

3. The above-mentioned actions are important in the context of an ageing society.

The results of the study may be a prerequisite for the modification of the national blood donation and blood treatment policy in Poland in terms of the choice of methods for developing public awareness of the importance of blood donation.

The results of the empirical research could be used by the scientific community, and above all, in practice - in managing and supervising the system of blood donation and transfusion in Poland (the Ministry of Health, the National Blood Centre, regional centres of blood donation and blood treatment), and by others interested in the issues of health care. 


\section{Research limitations}

The authors of this study are aware of unequal brackets in the studied age categories, and the possibility to take into account another set of structural and geographic effects having an impact on the status and structure of blood donors and blood components in the study. These relationships are more complex. The results prompt the authors to identify other factors affecting the structure of blood donors and examine the relationship between these factors, which will be the subject of the authors' future work.

\section{References}

Cieślak M. (1992), Demografia. Metody analizy i prognozowania, Wydawnictwo Naukowe PWN, Warszawa.

Creamer D. (1942), Shift of Manufacturing Industries, Industrial Location and National Resources, U.S. Government Printing Office, Washington.

Directive 2002/98/EC of the European Parliament and of the Council of 27 January 2003.

Márquez M.A., Ramajo J., Hewings G.J.D. (2009), Incorporating sectoral structure into shift-share analysis, "Growth and Change", vol. 40(4), pp. 594-618.

Mioduszewska M. (2008), Najnowsze migracje z Polski ws świetle danych Badania Aktywności Ekonomicznej Ludności, OBM WNE UW, Warszawa.

Nazara S., Hewings G.J.D. (2004), Spatial Structure and Taxonomy of Decomposition in shift-share analysis, "Growth and Change", vol. 35, pp. 476-490.

Suchecki B. (2010), Ekonometria przestrzenna, Wydawnictwo C.H. Beck, Warszawa.

Szołtysek J., Twaróg S. (2009), Gospodarowanie zasobami krwi jako nowy obszar stosowania logistyki, "Gospodarka Materiałowa i Logistyka", no. 7, pp. 12-17.

Szołtysek J., Twaróg S. (2010), Korzyści ze stosowania logistyki w zarządzaniu systemem cywilnego krwiodawstwa w Polsce, "Logistyka", no. 6, pp. 14-17.

Trzpiot G., Ojrzyńska A., Szołtysek J., Twaróg S. (2013), Wykorzystanie shift share analysis w opisie zmian struktury honorowych dawców krwi w Polsce, "Studia Ekonomiczne", Uniwersytet Ekonomiczny w Katowicach, no. 162, pp. 84-98.

Twaróg S. (2012), Logistyczne aspekty zarządzania łańcuchami dostaw krwi w Polce, Uniwersytet Ekonomiczny w Katowicach, Katowice (unpublished $\mathrm{PhD}$ thesis).

Twaróg S. (2013), Czynniki sukcesu systemu krwiodawstwa w Polsce, "Studia Ekonomiczne", Uniwersytet Ekonomiczny w Katowicach, no. 175, pp. 92-103.

Twaróg S. (2015), Scenariusze rozwoju systemu zarzadzania logistycznego cywilnym krwiodawstwem w Polsce. Part I, "Logistyka”, no. 4, pp. 25-29. 


\section{Użyteczność przestrzennej analizy dla poprawy funkcjonowania systemu krwiodawstwa w Polsce}

Streszczenie: Celem artykułu jest ukazanie, jak kształtują się zasoby krwi na wejściu do systemu cywilnego krwiodawstwa w Polsce na podstawie analizy dynamiki zmian w strukturze głównej determinanty sukcesu krwiodawstwa (dawców) oraz sformułowanie rekomendacji zmierzających do poprawy bezpieczeństwa zdrowotnego państwa w obszarze samowystarczalności zasobów krwi. Za sukces funkcjonowania krwiodawstwa uznano przede wszystkim takie zarządzanie zasobami krwi i jej składnikami, które dąży do zrównania popytu i podaży na krew i jej składniki w każdym momencie. Taka sytuacja jest możliwa, gdy dysponuje się wystarczającą liczbą dawców. W badaniu wykorzystano analizę przesunięć udziałów, która służy do badania zmian strukturalnych zjawisk ekonomicznych i społecznych, mogących zachodzić w przestrzeni geograficznej w określonym przedziale czasu. Aby uwzględnić to, że każde województwo nie występuje jako odrębny geograficznie obszar, tylko zależy od przestrzennych interakcji z sąsiadującymi obszarami, w badaniu wykorzystano również przestrzenną analizę przesunięć udziałów. Otrzymane wyniki posłużą ocenie dynamiki zmian liczby dawców wynikającej ze struktury wieku dawców krwi w poszczególnych województwach (efekt strukturalny) i ze zmian konkurencyjności danego obszaru (efekt geograficzny). Znajomość natury zmian może być pomocna przy kształtowaniu konkretnych narzędzi oddziaływania na dawców (w tym również potencjalnych).

Słowa kluczowe: krwiodawstwo, współczynnik selektywności migracji, analiza przesunięć udziałów, przestrzenna analiza przesunięć udziałów

JEL: R15

\begin{tabular}{|l|l|}
\hline OPEN ACCESS & $\begin{array}{l}\text { C) by the author, licensee Łódź University - Łódź University Press, Łódź, Poland. } \\
\text { This article is an open access article distributed under the terms and conditions } \\
\text { of the Creative Commons Attribution license CC-BY } \\
\text { (http: //creativecommons.org/licenses/by/3.0/) }\end{array}$ \\
\cline { 2 - 2 } \\
Received: 2017-01-07; verified: 2017-09-11. Accepted: 2018-02-16
\end{tabular}

